\title{
APOA1 wt Allele
}

National Cancer Institute

\section{Source}

National Cancer Institute. APOA1 wt Allele. NCI Thesaurus. Code C116418.

Human APOA1 wild-type allele is located within 11q23-q24 and is approximately $2 \mathrm{~kb}$ in length. This allele, which encodes apolipoprotein A-I protein, plays a role in cholesterol metabolism and transport. Mutation of the gene is associated with several types of amyloidosis, APOA1 deficiency, hypoalphalipoproteinemia, autosomal recessive corneal clouding, and high density lipoprotein deficiency types 1 (recessive) and 2 (autosomal dominant). Fusion of this gene with the neighboring APOC3 gene is associated with combined apoA-I and apoC-III deficiency. 